\title{
BUDGETING AS A PANACEA TO SPORTS DEVELOPMENT IN
}

\section{UNIVERSITIES IN SOUTH-SOUTH NIGERIA}

\section{EDENEDO EDWARD EDIRIN ${ }^{1}$, AKARAH EMMANUEL OGHENEBRORIEN ${ }^{2}$ \& TAYIRE FAVOUR OKAGBARE ${ }^{3}$ \\ ${ }^{1,2}$ Department of Human Kinetics \& Health Education, Delta State University, Abraka, Nigeria}

${ }^{3}$ Department of Human Kinetics \& Health Education, Delta State College of Education, Mosogar, Delta State, Nigeria

\begin{abstract}
Sports development entails a continued improvement of a sports structure, its constitutions, and programmes so as to create a social condition that would ensure physical fitness for all with accompanying effective functioning and self-actualization while budgeting is the process of creating a plan to spend money whilst estimating the judicious use of resources. The descriptive survey research design was adopted for the study with a population of two hundred and thirty four (234) that purposively constituted the sample comprised of the Chairmen of Universities Sports Councils, Sports Directors, Deputy Sports Directors, Chief Sports Coach, Principal Sports Coach, Senior Sports Coach as well as Sports Coaches I and II. A forty-five (45) item questionnaire from which five items were extracted to test budgeting with a reliability index (r) of 0.89 established with the Pearson's Product Moment Correlation and rated on a five- point Likert type scale of Very High (VH) to Very Low (VL). The findings of the study revealed that budgeting is a panacea to sports development in the universities in South-South Nigeria. The study recommended training on budgeting principles and the advantages of preparing annual budgets for sports personnel in the universities.
\end{abstract}

KEYWORDS: Budgeting, Sports Development, Sports Facilities \& Financial Resources

Received: Mar 20, 2018; Accepted: Apr 10, 2018; Published: May 08, 2018; Paper Id.: IJESRJUN201810

\section{INTRODUCTION}

Sports development, according to the Nigeria policy of sports development $(1989,2007)$ is the process of continuous improvement of a sport structure, its constitutions and programmes in order to create a social condition that can ensure physical fitness for all, which will in turn bring about the effective functioning of the individual so as to ensure self-actualization. Venkateswarlu (1999), conceptualized sports development to entail the improvement in sports facilities to enable the individual to participate for fitness, represent the institution or the country.

The Federal Republic of Nigeria Economic Transformation Blueprint (2009) Vision 20:2020, which seeks to place Nigeria among the World's first twenty countries by the year 2020 recognizes the role of sports in actualizing this feat and, stresses the need for sports facilities in primary, secondary and tertiary institutions. It identifies the role of the youth in growing the national economy and stresses that sporting activities could be used in engaging the youth so as to effectively keep them off drugs, crime, and irresponsible sexual behavior.

The Nigeria Universities Games Association (NUGA) is the body that organizes sports competitions in which all universities are expected to participate. The universities vie for hosting rights which is usually granted 
based on the level of preparedness for such. Ensuring that sports facilities are available and the standard should be a priority in grooming and be presenting athletes for this competition and for sports development.

Budgeting which entails the process of creating a plan to spend money involves a planning process of human, material and financial facets while estimating the judicious use of resources. It is ,in fact, another crucial step in the attainment of success in any sports endeavor. (Chima, 2012) It thus will not be an overstatement when Igbanugo (2003), noted that the role money plays in the successful hosting and development of sports cannot be overemphasized. Undoubtedly, facilities and equipment cannot be procured for sporting activities if budgetary allocations are not made for such just as, human resources cannot be adequately motivated through remunerations that would foster optimum performance in sports participation.

A study by Omolowon and Adisa (2009) on the impact of budgeting in the tertiary institutions in Osun State, Nigeria using a sample size of five hundred (500) respondents revealed that budgeting is one of the key factors in sports administration towards sports development. Ayanlaja (2007) had noted that success in sports is largely determined by the availability and allocation of financial resources to prosecute the various sports development programmes.

There is no doubt that an administrator who strives to attain the goals and objectives of the physical education and sports programmes by procuring equipment, constructing facilities and maintaining same as well as recruiting staff would have to make annual budgetary preparations (Igbanugo, 1986 in Udo et al).

The Event Administration Body of Knowledge (EMBOK, 2005) theory noted that financial resources which are usually limited need be acquired and utilized in the most efficient manner for the benefit of an event programme. A Budget is a financial document used to project future income and expenses. The budget process may be carried out by the administrator with some other individuals, including the higher sports officers and the overall sports head which would then be submitted to the bursar who would ,in turn, forward the prepared budget to budget consideration committee. The committee would be expected to invite the Director of Sports for final defense and approval. The budget would be expected to contain a listing of all sources of monthly income including sales and interest, as well as all required fixed expenses (www.businessdictionary.com/definition/budget). Budgeting and fiscal administration are not only tools of administration, but the main instruments by which decision makers plan their activities over a period of time.

Budgeting according to Cole (2000) is a key determinant of a manager. He opined that budgeting is a statement usually expressed in financial terms, of the desired performance of an organization in the pursuit of its objectives in the short term usually a year. Atoyebi (1992) also stated that budgeting is a part of the administration control process by which resources are obtained and used efficiently in the accomplishment of administrative objectives. Chima (2012) opined that budgeting is a planning process which states the financial inputs and expenditure of human, material, and financial resources while estimating the judicious use of resources. Fasan (1994) further supported the efficacy of budgeting towards administration when he stated that without adequate budgeting procedures, there will be a misappropriation, wastage of resources leading to a poor event outcome. He defined budgeting in sports as a process that helps to link programmes and activities with the financial outlay so as to accomplish the stated objectives, prevent wastage and complement human efforts.

Morakinyo and Aluko (2009) noted that the success of any sports programme depends largely on the availability of funds. Without adequate finance, sports development in Nigeria will be comatose. Funds are the basic foundations on 
which other things are laid. They further noted that one of the most crucial functions of a sports administrator involves securing the funds needed to provide sound sports programmes. Adequate funding must be procured, programmed and a budget planned with implementation and accountability for funds established. Finances are the engine that drives the total administration process of an organization.

Bucher (1984) as cited by Omolawon (2003) stated that apart from making sure that policies for raising and spending money must be well reasoned out, persons responsible should know the procedures for handling such funds with integrity, an understanding of the basic purpose for which the programme exists, the laws, codes, and regulations regarding fiscal administration. Abdul (2003) posited that sports managers should understand the role that finance plays in the development of sports programmes/organizations, highly skilled with awareness on recent trends in the preparation of the budget and in such manner that would instill in them, prudence and accountability. Igbanugo (2003) noted that the role money plays in the successful hosting and development of sports cannot be over-emphasized. This is due to the fact that without money, facilities and equipment cannot be procured for sporting activities, human efforts cannot be compensated, and state-of-the-art facilities cannot be used in organizing sports events. Furthermore, human resources cannot be adequately motivated, remunerations and souvenirs may not be provided for participants resulting in the likelihood of reducing the number of participants and optimum performance in subsequent sports activities.

It would be imperative to add that, the process of planning the budget should take into cognizance, a selection and purchase of items that would meet the objectives of the programme as well as the needs of the students, quality of the materials so listed need be verified while the materials selected should be purchased from reputable manufacturers. The attitude of university students toward sports participation is usually influenced by such factors as the availability of standard facilities and equipment ,therefore, the planning for and acquisition of adequate sports facilities and equipment is indicative of administrative competence.

Ojeme (2005) opined that physical education facilities and equipment require huge capital outlay and therefore require a total financial commitment by those at the administrative helm in the university sports unit. He further added that if facilities and equipment are adequately provided and maintained at regular interval there is definitely going to be greater participation by gifted students in the course of any sports competition. The National Sports Policy $(1989,2007)$ and the Federal Government Report on Vision 2010 (1997), did recognize the importance of sports facilities to the development of sports in any nation. This was why the policy advised that the government should provide adequate funds which will be used in procuring adequate facilities and equipment in the schools.

\section{Research Method}

The descriptive survey research design was adopted for the study. The population of this study is two hundred and thirty- four (234) respondents comprised of chairman of the Sports Council, Sports Directors, Deputy Sports Director, Chief Sports Coach, Principal Sports Coach, Senior Sports Coach, Sports Coach I, Sports Coach II, and Assistant Coach from private, state and federal universities in South-South Nigeria. The entire population, two hundred and thirty- four (234) was purposively sampled since they constitute the administrative heads in the sports unit in the various universities.

A forty-five (45) item self-structured questionnaire whose reliability index (r) was established at 0.89 with the Pearson's Product Moment Correlation from which five items were extracted to seek responses on budgeting was used for the collection of data in the Universities in South-South Nigeria. The questionnaire was structured on a modified five 
points Likert type rating scale of Very High (VH) with five (5) points, High (H) with four (4) points, Moderate (M) with three (3) points, low (L) with two (2) points and Very Low (VL) with one (1) point.

\section{Research Question}

To what extent will budgeting be a panacea to sports development in the Universities in South-South Nigeria?

Table 1: Extent to Which Budgeting will be A Panacea to Sports Development in the Universities in South-South Nigeria

\begin{tabular}{|c|c|c|c|c|c|c|c|}
\hline \multirow{2}{*}{$\begin{array}{c}\text { Items On The Extent To Which } \\
\text { Budgeting Enhances Sports } \\
\text { Development }\end{array}$} & \multicolumn{5}{|c|}{ Responses Measure of Extent } & \multirow[b]{2}{*}{ Mean } & \multirow[b]{2}{*}{ Std. Dev } \\
\hline & Very High & High & Moderate & Low & Very Low & & \\
\hline $\begin{array}{l}\text { To what extent would budgeting entail } \\
\text { judicious utilization of financial } \\
\text { resources? }\end{array}$ & $41(17.5 \%)$ & $193(82.5 \%)$ & $0(0.0 \%)$ & $0(0.0 \%)$ & $0(0.0 \%)$ & 4.18 & .38 \\
\hline $\begin{array}{l}\text { To what extent would budgeting promote } \\
\text { the activities of subordinates working as } \\
\text { committee by allocating the needed funds } \\
\text { for the actualization of primary tasks for } \\
\text { sports development? }\end{array}$ & $86(36.8 \%)$ & $140(59.8 \%)$ & $8(3.4 \%)$ & $0(0.0 \%)$ & $0(0.0 \%)$ & 4.33 & .54 \\
\hline $\begin{array}{l}\text { To what extent would budgeting help in } \\
\text { establishing remuneration to motivate } \\
\text { athletes in subsequent participations for } \\
\text { sports development? }\end{array}$ & $109(46.6 \%)$ & $18(7.7 \%)$ & $107(45.7 \%)$ & $0(0.0 \%)$ & $0(0.0 \%)$ & 4.01 & .96 \\
\hline $\begin{array}{l}\text { To what extent would budgeting make } \\
\text { financial plans to procure state-of-the art } \\
\text { facilities and equipment for sports } \\
\text { development? }\end{array}$ & $31(13.2 \%)$ & $194(82.9 \%)$ & $18(7.7 \%)$ & $9(3.8 \%)$ & $0(0.0 \%)$ & 4.09 & .40 \\
\hline $\begin{array}{l}\text { To what extent would budgeting reduce } \\
\text { the misappropriation of funds for sports } \\
\text { development? }\end{array}$ & $71(30.3 \%)$ & $143(61.1 \%)$ & $20(8.5 \%)$ & $0 .(0.0 \%)$ & $0(0.0 \%)$ & 4.22 & .59 \\
\hline Grand Mean & $\begin{array}{c}67.6 \\
(28.88 \%)\end{array}$ & $137.6(58.8 \%)$ & $30.6(13.06 \%)$ & $00.0 \%)$ & $0(0.0 \%)$ & 4.17 & 0.57 \\
\hline
\end{tabular}

Table 1 shows that the extent to which budgeting will be a panacea to sports development in the universities in South-South Nigeria had a grand mean of 4.17and a standard deviation of 0.57 . This grand mean value of 4.17 is higher than the criterion mean of 3.00. The research question which stated that "To what extent will budgeting is a panacea sports development in the Universities in South-South Nigeria?" was therefore answered that budgeting was found to be a panacea to sports development in the Universities in South-South Nigeria to a very high extent.

\section{Hypothesis}

Budgeting would not significantly be a panacea to sports development in the Universities in South-South Nigeria.

Table 2: Multiple Regression Coefficients

\begin{tabular}{|l|c|c|c|c|}
\hline $\begin{array}{c}\text { Administrative } \\
\text { Principle }\end{array}$ & \multicolumn{2}{|c|}{ B } & T & Sig \\
\hline & $\begin{array}{c}\text { Un Standardised } \\
\text { Coefficients }\end{array}$ & $\begin{array}{c}\text { Standardized } \\
\text { Coefficients }\end{array}$ & & \\
\hline Constant & 32.49 & 0.22 & 7.96 & 0.00 \\
Budgeting & 0.29 & 2.55 & 0.01 \\
\hline
\end{tabular}

Dependent Variable: Sports Development.

Table 2 above reveals that budgeting has standardized $B$ coefficient $(B=-0.22, t=2.55)$ that are significant at 0.01. Therefore budgeting was found to be a significant panacea to sports development in the universities in South-South Nigeria thus the hypothesis was rejected. 


\section{DISCUSSION OF FINDINGS}

The findings of the study revealed that budgeting is a panacea to sports development in the universities in SouthSouth Nigeria. It is imperative that necessary and adequate plans be made on how much finances are available; identify the areas of need and a plan made on how such finances would be spent to achieve stated objectives. Thus, the financial input and expenditure to be incurred become the parameters that would determine how much success would be attained towards developing sports in the universities. This finding is supported by Ayanlaja (2007) when he noted that success in sports is largely determined by the availability of financial resources to execute various sports development plans and one mechanism for attaining proper utilization of financial input is through budgeting procedures. The finding of the study is also supported by Omolowon and Adisa (2009) who stated that budgeting is one of the key factors in sports administration towards sports development.

\section{CONCLUSIONS}

The study has revealed that budgeting is a panacea to sports development in the universities in South - South Nigeria. The goals and objectives of sporting, recreation, and physical fitness programmes cannot be attained in the absence of sports facilities and equipment. If the universities are to participate in intra (inter-Faculty) and inter (NUGA) universities sports competitions, the roles of standard, state of the art and modern sports facilities and equipment which are indices of sports development cannot be ruled out. In a bid to procure and maintain these facilities and equipment, it will be imperative to plan through budgeting, how monies that have accrued for this purpose be spent so as to meet with the stated goals and objectives of the various universities especially if sports have to be developed.

\section{RECOMMENDATION}

It is imperative that the Director of sports, coaches and all other sports personnel in the universities be trained through workshops, seminars, conferences and in-service programmes on budgeting principles and the advantages of preparing annual budgets that would stimulate the processes of sports development.

\section{REFERENCES}

1. Abdul, A. A. (2003). Determinants of organization of intramural sports in Lagos State secondary schools. The Official Magazine of the International Council for Health, Physical Education, Recreation, Sports and Dance: African Region. Proceedings from the 1st ICHPER-SD African Regional Conference. Pp. 62.

2. Atoyebi, O. A. (1992). Relationship between facilities Equipment, personnel funding of sports and Athletic achievement. Journal of Nigeria Academic of sports Administration (3), 24-31

3. Ayanlaja, A. O. (2007). Budgeting as a factor influencing the planning and administration of intramural sports programmes in Lagos State owned tertiary institutions in Nigeria. Ibadan: Bayosoye printing services.

4. Chima S. U. (2012). Integration of administrative processes in School administration. Retrieved from www.journals.Savap.org.pkon the 13/04/2016

5. Cole, G. A. (2000). Measurement theory and practice (5 ${ }^{\text {th }}$ ed.) London: Ashford Press Company

6. Fasan, C. O. (1994). Introduction to sports administration. Lagos: Beulah publisher

7. Federal Republic of Nigeria (1989). Sports development policy for Nigeria (Revised). Lagos, Federal Government of Nigeria.

8. Federal Republic of Nigeria (2007). Sports development policy for Nigeria. Lagos: Federal Ministry of Youths and Sports. 
9. Federal Republic of Nigeria (2009). Nigeria Vision 20:2020 Economic Transformation Blueprint. Abuja, Federal Government of Nigeria.

10. Igbanugo, V. C. (1986). Organization of sports relationship to performance. In G. O. Udoh, A. S. Soli and J. A. Ayala (Ed). Organization of Sports for Nigeria Universities, NUGA 86 Proceedings. Bodya Clavier Printing Press.

11. Igbanugo, V. C. (2003). Science and research: The Ultimate means of developing sports excellence. Ibadan: Stirlen - Horden Publisher Nigeria Limited.

12. Jehanzeb, Khawaja, Anwar Rasheed, and Mazen F. Rasheed. "Organizational commitment and turnover intentions: impact of employee's training in private sector of Saudi Arabia." International Journal of Business and Management 8.8 (2013): 79.

13. Morakinyo, E. O. \& Aluko, E. O. (2009). Administration factors of sports development in selected sports federation of the Federal Ministry of sports and social development in Nigeria. Retrieved from http://ojc.sive.edu/ojs/index.php/ijaas/article/viewfile/106/166 on 18/09/20 13.

14. Ojeme, E. O. (2005). Towards the effective implementation of physical education and sports curriculum in the universal basic education programme. Journal of Nigeria Association of Physical, Health Education, Recreation. Sports and Dance JONAPHER. SD. 2 (1), 1-14.

15. Omolawon (2003). Parameter influencing the propagation of physical education and sports programmes in Nigeria schools. The official magazine of the International Council for Health, Physical Education, Recreation, Sports and Dance: African

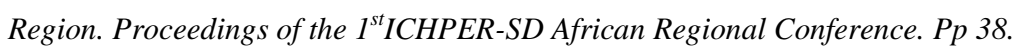

16. Omolawon, K. O. \& Adisa, O. (2009). Budgeting planning allocation and implementation as indices of intramural sports programme among Osun state owned tertiary institutions. Nigerian Journal of Sports Administration 10 (3), 24-26

17. The Event Administration Body of Knowledge (www.EMBOK.org) retrieved on the 20/05/2013.

18. Venkateswarlu, K. (1999). Sports development: Institutional sports and physical education in schools. Seminar Paper on "Sports Development in Nigeria in the Next Millenium", Abuja, $24^{\text {th }}-26^{\text {th }}$ August.

19. www.Businessdirectionary.com/definition/budget. Retrieved on the 17/12/13 www.ehow.com>ehow>sport \& fitness retrieved $17 / 12 / 13$ 